\title{
Current and potential management strategies against Harmonia axyridis
}

\author{
Marc Kenis · Helen E. Roy $\cdot$ Renate Zindel $\cdot$ Michael E. N. Majerus
}

\begin{abstract}
This paper reviews the current and potential methods to control the harlequin ladybird, Harmonia axyridis (Pallas) (Coleoptera: Coccinellidae), an Asian predatory beetle invasive in Europe and the Americas where it has become a human nuisance, a grape and wine pest and a threat to native biodiversity. Current methods to manage this invasive species include: techniques to mechanically prevent adult beetles from entering buildings in autumn or to remove aggregates of beetles inside buildings, e.g. using various trapping methods; the use of insecticides on buildings or in vineyards to prevent aggregation in houses or on grapes; cultivation practices in vineyards to lower the impact of the ladybird on grape production and wine quality; remedial treatments for wine tainted by the ladybird. Other methods are presently being developed or considered. Semiochemicals could be used as deterrents or as attractants to develop more efficient trapping systems in buildings and open fields. Natural enemies include pathogens, parasitoids, predators and a parasitic mite but few of them show potential as biological control agents. While management methods presently used or under development may eventually solve the problems caused by beetles aggregating in buildings or vineyards, the issue of $H$. axyridis populations outcompeting native species is much more challenging. Only the sudden adaptation of a native natural enemy or the importation of a natural enemy from the area of origin of the ladybird may
\end{abstract}

M. Kenis $(\bowtie) \cdot R$. Zindel

CABI Europe-Switzerland, 1, Rue des Grillons, 2800 Delemont, Switzerland

e-mail: m.kenis@cabi.org

H. E. Roy

NERC Centre for Ecology and Hydrology Monks Wood, Huntingdon PE28 2LS, UK

e-mail: hele@ceh.ac.uk

R. Zindel

Department of Biology, Unit of Ecology and Evolution, University of Fribourg, Chemin du Musée 10, 1700 Fribourg, Switzerland

e-mail: renatezindel@gmail.com

M. E. N. Majerus

Department of Genetics, University of Cambridge, Downing Street, Cambridge CB2 3EH,

England, UK

e-mail: m.majerus@gen.cam.ac.uk 
ultimately lower population densities. The problems linked to the importation of an Asian natural enemy of $H$. axyridis are discussed.

Keywords Harmonia axyridis - Integrated pest management - Biological control · Mechanical control · Chemical control · Cultivation practices · Parasitoids · Entomopathogenic fungi · Parasitic mites

\section{Introduction}

Harmonia axyridis (Pallas) (Coleoptera: Coccinellidae), the harlequin ladybird, or multicoloured Asian ladybeetle, is a polyphagous predatory coccinellid, native to central and eastern Asia. It has been widely used as a biological control agent of aphids in the Americas and Europe, in greenhouses as well as in outdoor crops (Koch 2003; Pervez and Omkar 2006). In North America, since its establishment in the 1980s, it has spread and increased dramatically so that it is now the dominant ladybird species in much of the USA and Canada (Koch and Galvan 2007). Three categories of hazards caused by this invasive ladybird are reported (Koch et al. 2006). First, it is considered as a human nuisance because it aggregates in buildings when seeking overwintering sites, causing cosmetic damage and, occasionally, biting humans and causing allergic reactions (McCutcheon and Scott 2001; Huelsman and Kovach 2004; Kovach 2004; Ray and Pence 2004). Second, $H$. axyridis has been reported to damage fruit crops in late summer and to taint wine when harvested and crushed with grapes (Koch et al. 2004; Kovach 2004; Pickering et al. 2005). Finally, due to its predatory and competitive abilities, $H$. axyridis may have strong negative effects on biodiversity, affecting many non-target species, including native ladybirds and other aphidophagous insects but also non-pest aphids or other herbivorous insects (see reviews by Majerus et al. 2006 and Koch and Galvan 2007).

In Europe, H. axyridis has been released in the wild since 1990 (Brown et al. 2007). Since the first observations of feral populations were reported in 1999 in Germany and in Belgium in 2001, numbers have increased exponentially and it is now regarded as established in 12 European countries (Brown et al. 2007). In Belgium, recent surveys showed that $H$. axyridis has become by far the most abundant ladybird on broadleaved trees (Adriaens et al. 2007).

Since the establishment of $H$. axyridis in North America, this invasive ladybird has been the target of numerous research programmes, which have been summarised in several review articles (e.g. Adriaens et al. 2003; Koch 2003; Majerus and Roy 2005; Koch et al. 2006; Pervez and Omkar 2006). None of these reviews, however, cover the currently used and potential management methods to control H. axyridis.

Several methods are presently implemented or being studied to control the ladybird in North America. These methods differ according to the three main types of hazards caused by the beetle (aggregation in buildings, damage to fruits and wine and competition with the native fauna). Most management methods, proposed so far, concern preventive or curative control against ladybird aggregation in houses or in vineyards. No method is presently available to lower population densities in natural environments and to limit the impact of the ladybird on native species.

\section{Mechanical control and trapping methods}

Numerous extension documents in North America describe methods to mechanically prevent adult beetles from entering buildings in autumn or to remove aggregates of beetles 
inside buildings (e.g. McCutcheon and Scott 2001; Jones and Boggs 2002; Baniecki et al. 2004; Potter and Townsend 2005). Recommendations to prevent the entrance of beetles in buildings include: checking for all possible entry sites; sealing windows, cracks and small holes throughout the house with weather stripping; placing insect screening over windows, attic, exhaust vents, etc. To remove large aggregates of beetles in buildings, the use of a broom and dust pan or, better, a vacuum cleaner is recommended (Jones and Boggs 2002; Baniecki et al. 2004; Potter and Townsend 2005). Jones and Boggs (2002) describe how a vacuum cleaner can be modified to capture ladybirds and avoid them entering the vacuum by using a sweeper attachment with a knee-high nylon hose inserted in the end.

Various traps are recommended and commercially available to catch adult beetles in buildings (Banieki et al. 2004). Black light traps and other light traps can be used for capturing beetles in dark confined places such as attics. Window traps may be effective during daytime. Although it has been suggested that these traps could reduce beetle populations by 50-70\% (Jones and Boggs 2002; Banieki et al. 2004), thorough testing is required to ascertain whether they provide a solution for large infestations of $\mathrm{H}$. axyridis (Jones and Boggs 2002; Potter and Townsend 2005). Furthermore, it is highly unlikely that light traps could efficiently control ladybirds in outdoor conditions, e.g. in vineyards or orchards. The efficiency of trapping methods in buildings and open field could be greatly enhanced by coupling with semiochemicals. There are many examples in the literature of insects using olfactory communication for dispersal, migration, reproduction, aggregation and alarm signalling (reviewed in a pest control context by Van Emden and Service 2004). Over the last 30 years the behavioural manipulation of insects through semiochemical techniques (for example: push-pull strategies) has been considered for the control of insect populations, with varying success (Cook et al. 2007). However, our theoretical understanding of insect semiochemistry has increased enormously in recent years (reviewed by Hassanali et al. 2005; Cook et al. 2007; Roy et al. 2008) and applications exploiting this knowledge, within pest control strategies, are being developed further. Pheromones have been used within integrated pest management (IPM) strategies for: monitoring pest populations, trapping out pest populations ("lure and kill"), confusing pests (saturating a crop environment with synthetic pheromones to prevent males locating females), deterring oviposition and manipulating or encouraging natural enemies.

Information on semiochemically-mediated behavioural mechanisms of coccinellids is limited (Pettersson et al. 2005) but there are sufficient recent studies to suggest that, like other insects, chemical communication is an important component of ladybird behaviour (Burns et al. 1998; Hemptinne et al. 2004; Pettersson et al. 2005). The use of autumn aggregation pheromones for the location of suitable overwintering sites perhaps has the most significant potential for use in a control strategy. It has been widely speculated that many species of ladybirds use species-specific aggregation chemicals in preparation for dormancy (Majerus 1994). Hills (1969) suggested that Adalia bipunctata (L.) (Coleoptera: Coccinellidae) used pheromonal volatiles from the excretal remains of individuals overwintering the previous year. Majerus (1994) demonstrated that A. bipunctata were less likely to locate sites that had been washed between overwintering events, providing strong circumstantial evidence of a long lasting, aggregation pheromone. In a more recent study, Pettersson et al. (2005) demonstrated that Coccinella septempunctata L. (Coleoptera: Coccinellidae) use an autumn aggregation pheromone to locate overwintering sites. There is no current information on the chemical nature of these aggregation pheromones or whether they are species specific or, indeed, seasonally specific (active only in autumn). Nalepa et al. (2000, 2005) investigated factors influencing aggregation behaviour and found little evidence for volatile aggregation pheromones. Their results suggest that beetles 
are rather attracted by visual intensity contrast and by contact chemoreception with conspecifics or the faeces and residues that persist in aggregation sites from previous years. However, if an aggregation semiochemical specific to $H$. axyridis could be produced, it would be possible to utilise this in a "lure and kill" strategy for controlling this species in sensitively determined areas. A recent paper suggests that two volatile sesquiterpenes, (E)- $\beta$-farnesene (aphid alarm pheromone) and (-)- $\beta$-caryophyllene (isolated from the headspace volatiles above $H$. axyridis aggregations in winter), are ecologically relevant to $H$. axyridis (Verheggen et al. 2007). (E)- $\beta$-farnesene elicited electroantennogram (EAG) and behavioural responses within an olfactometer in both male and female $H$. axyridis. In contrast, (-)- $\beta$-caryophyllene resulted in EAG and behavioural activity (attraction) in male $H$. axyridis but only EAG activity in female beetles (no associated behavioural response within an olfactometer). However, interestingly, Verheggen et al. (2007) demonstrated in a bioassay that both male and female $H$. axyridis aggregated in the (-)- $\beta$-caryophyllenetreated side of a ventilated plastic box as opposed to the untreated side. Perhaps the presence of the male $H$. axyridis evokes the response of the females. The authors conclude that (E)- $\beta$-farnesene and (-)- $\beta$-caryophyllene could have potential use within a push-pull control strategy for $H$. axyridis, but it is possible that $H$. axyridis exhibits different antennal sensitivity to (-)- $\beta$-caryophyllene in relation to season, responding more in winter. The complexity of insect behavioural responses to semiochemicals should be assessed thoroughly when considering manipulating insects as a component of an IPM strategy.

Trapping methods based on aggregative pheromones are commonly used for the monitoring and control of scolytid bark beetles (Byers 2004). A sap beetle, Carpophilus lugubris Murray (Coleoptera: Nitidulidae) was successfully controlled at overwintering locations, with minimal impacts on other insect species, using an autoinoculative device baited with aggregation pheromone and the fungal pathogen Beauveria bassiana (Balsamo) Vuillemin (Ascomycota: Hypocreales) (Dowd and Vega 2003). A combination of the fungal pathogen Metarhizium anisopliae (Metsch.) Sorokin (Ascomycota: Hypocreales) and an attractant (phenethyl propionate:eugenol:geraniol) has shown potential for controlling Japanese beetle Popillia japonica Newman (Coleoptera: Scarabaeidae) (Klein and Lacey 1999). These systems could be appropriately designed for controlling H. axyridis, however, recent studies have shown that $H$. axyridis is relatively resilient to fungal (B. bassiana) mortality (Roy et al. 2007). It is possible that a synthetic insecticide could be used in an attractant trap which would provide a targeted method of control with limited impacts on non-target insects and the environment.

\section{Chemical control}

Many insecticides have been tested against $H$. axyridis, but rather to test the non-target impact of insecticides used against aphids and other pests than to assess their potential use against the ladybird (see Koch 2003, for a review, and Galvan et al. 2005a, b, 2006d for the most recent investigations). These studies showed that most insecticides commonly used in agricultural environments are toxic to $H$. axyridis. Larvae were more sensitive than adults and, in general, the toxicity of the insecticides was lower to the ladybird than to aphids. Galvan et al. (2006a), Inclan et al. (2006) and Williams et al. (2006) recently carried out field and laboratory evaluation of the efficacy and suitability of insecticides for management of $H$. axyridis in vineyards. One of the limiting factors of using insecticides is that many of them, e.g. most pyrethroids, have a pre-harvest interval of several weeks whereas, to be efficient, treatments should be applied within a week before harvest (Galvan et al. 
2006a). Among the most efficient compounds, only carbaryl and imidacloprid were labelled for use on wine grape within 7 days of harvest in USA at the time of the study (Galvan et al. 2006a). Insecticide treatments against $H$. axyridis in vineyards should not be carried out preventively but should rather follow decision protocols based on rigorous sampling plans and well defined action thresholds (Galvan et al. 2006a, 2007). In addition, the potential effect of such treatments on non-target beneficial organisms should be investigated.

In North America, it is sometimes advised to apply insecticides, as a preventive method, to the exterior of buildings that are regularly infested year after year (McCutcheon and Scott 2001; Jones and Boggs 2002; Baniecki et al. 2004; Potter and Townsend 2005). Application of a residual formulation of synthetic pyrethroids (e.g. bifenthrin, cyfluthrin, cypermethrin, deltamethrin, etc.) to walls and sidings, around eaves, attic vents, windows, doors and other likely points of entry, in late-September-October, i.e. just before beetles enter the structure is recommended. Insecticide use inside buildings is usually not advised (McCutcheon and Scott 2001; Potter and Townsend 2005) and the application of chemicals in other overwintering sites has never been considered.

\section{Deterrents}

Deterrents could be employed to reduce $H$. axyridis populations in locations where their presence is undesired, for example, houses used as overwintering locations and vineyards. Harmonia axyridis reduces rates of feeding and oviposition in the presence of conspecific faeces but not with the faeces of Propylea japonica (Thunberg) (Coleoptera: Coccinellidae); whereas $P$. japonica reduces feeding and oviposition in response to faeces of conspecifics and $H$. axyridis (Agarwala et al. 2003). This is hypothesised to reduce intra-guild predation (Agarwala et al. 2003). Further work could investigate the use of these pheromonal faecal volatiles as deterrents for $H$. axyridis. However, it is possible that these could act as deterrents to other ladybird species and so be detrimental by impacting on beneficial insects in agricultural systems. Some plant compounds, such as camphor or menthol have proved to be repellent to $H$. axyridis in field and laboratory tests and could be used to protect buildings (Riddick et al. 2000). However, under field conditions, camphor was ineffective after $48 \mathrm{~h}$ post-application (Riddick and Aldrich 2004). Laboratory bioassays also showed that $H$. axyridis is repelled by DEET ( $N, N$-diethyl-3-methylbenzamide), a widely used insect repellent. A formulation of DEET plus paraffin had repellent activity for 23 days in the laboratory, but has not been field-tested (Riddick et al. 2004).

\section{Cultivation practices in fruit production and remedial treatment for tainted wine}

H. axyridis is often reported as a pest of fruit production in North America (Koch 2003; Kovach 2004). Nevertheless, the few studies on feeding activity suggest that it rarely causes primary injury on fruits, but rather feeds on damaged fruits (Koch et al. 2004; Kovach 2004; Galvan et al. 2006b). The main impact of the ladybird as a fruit pest is in vineyards when it aggregates in clusters of grapes, in particular those containing damaged berries, and is processed with the grapes, resulting in tainted, unmarketable wine or juice (Pickering et al. 2005). Several recommendations on cultivation practices in vineyards have been suggested to lower the impact of the ladybird in regions where $H$. axyridis causes recurrent problems to fruits, although these recommendations are not always based on rigorous studies. Key components of an IPM strategy against $H$. axyridis in vineyards 
include proper surveys for beetle densities before harvest and the determination of a threshold density, to assist in management decisions. Galvan et al. (2007) have described various sampling plans and assessed their usefulness. They found binomial sampling plans to be more accurate methods to measure beetle densities than enumerative plans. Kovach (2004) and Pickering et al. (2007) evaluated the threshold density for wine contamination to be about 0.9 and $1.3-1.5$ beetle per $\mathrm{kg}$ of grapes, respectively, but the latter authors recommend a more conservative limit of $0.2-0.4$ beetles per $\mathrm{kg}$ of grapes above which interventions in the field or in the winery should be considered. Including berry injuries in the sampling procedures may also be useful since ladybirds are primarily found on damaged fruits (Galvan et al. 2007). Such damage is caused by a variety of mechanisms including by splitting, feeding by birds or other insects, disease (rot) etc. (Galvan et al. 2007). Growers could reduce berry injury by using irrigation to avoid long periods of drought and by avoiding injuring to berries when pruning or spraying. Selecting varieties with higher resistance or tolerance to splitting may also be envisaged, as a potential longterm measure, when vineyards are replanted through the normal process of renewing stock.

Harvesting methods may have an impact on the density of beetles in harvested grapes. Beetles may be more likely to leave the grapes during day harvesting rather than during night harvesting (Anonymous 2005). Hand harvesting may be more favourable than mechanical harvesting because aggregations of beetles in grape clusters can be monitored during harvesting and infested grapes can be discarded. Beetles can be removed by shaker clusters, by hand or by using shaker tables, and by floating clusters in water or vacuum clusters (Galvan et al. 2006c). Shaker tables could also be used to monitor populations just before harvest. However, these methods result in significant increase in time, labour and costs of harvest (Galvan et al. 2006c). Managing the surrounding crops and vegetation could also be critical because beetles found in vineyards and orchards in autumn probably come from nearby aphid infestations. In North America, damage in vineyards is often associated with the presence of soybean infested by the soybean aphid, Aphis glycines Matsumura (Hemiptera: Aphididae), one of the preferred preys of $H$. axyridis, although the exact relationship between the proximity of soybean, soybean aphids and $H$. axyridis populations has not as yet been rigorously monitored.

Studies are being made on refining agents and other technologies to restore the quality of wine tainted by $H$. axyridis (Pickering et al. 2006). The main compound responsible for the taint is 2-isopropyl-3-methoxypyrazine (IPMP), a component of the reflex bleeding fluid of $H$. axyridis (Pickering et al. 2005). IPMP concentrations in wine could be lowered by activated charcoal in white wine and deodorized oak in red wine, although these treatments do not translate into lower intensity of the sensory attributes associated with the taint. In contrast, oak chips were successful in reducing the intensity of the taint characteristics, probably through a masking effect (Pickering et al. 2006). However, this method does not completely remove the taint from contaminated wine and, furthermore, it cannot be used for all wine types, since many of them are not normally oaked. Thus, other solutions that may be suitable for all wine types need to be sought. Pickering et al. (2006) suggest searching for a technology to target and selectively bind IPMP, with subsequent removal of the complex from the juice or wine.

\section{Biological control}

Natural enemies can be used in various ways to control an invasive insect such as H. axyridis (Van Driesche and Bellows 1996). First, a species could be introduced from the 
region of origin of the pest to the region of introduction for permanent establishment, a method often called "classical biological control". Second, in an "augmentative biological control" programme, natural enemies can be increased through regular inundative or inoculative releases. Finally, in a "conservation biological control" strategy, natural enemies already present on site can be favoured, e.g. through various cultural practices, to increase their impact on the target pest. All these methods could be developed and employed for controlling $H$. axyridis, albeit not with the same agents.

Natural enemies reported, or tested against $H$. axyridis comprise pathogens, predators, parasitoids, nematodes and a parasitic mite. There is little information available on the importance of natural enemies in the population dynamics of $H$. axyridis in field conditions, particularly in its region of origin. Research on mortality factors in field conditions has been carried out in Japan (Osawa 1992, 1993) and South Korea (Park et al. 1996), but natural enemies in the largest part of its distribution range, i.e. China and Russia, are largely unknown. In Europe and North America, observations suggest that natural enemies are of little importance in the population dynamics of the ladybird.

\section{Pathogens}

There have been a number of studies focussing on the impact of entomopathogens on coccinellids. Undoubtedly, the literature on fungal entomopathogens dominates this field and is mainly from the perspective of natural mortality in overwintering populations or, more usually, the effect of biorational pesticides on non-target coccinellids. Entomopathogenic fungi are common natural enemies of insects and other arthropods worldwide (Roy et al. 2006) and have considerable potential as biological control agents of pest insects.

Two Hypocrealean fungi have been found infecting ladybirds: M. anisopliae (Ginsberg et al. 2002) and B. bassiana (James et al. 1995; Cottrell and Shapiro-Ilan 2003; Roy et al. 2007). Most research on the direct interactions between fungi and ladybirds has concentrated on $B$. bassiana because of the potential non-target impact of this fungus when used as a mycoinsecticide against various pest insects. Susceptibility of various ladybirds (Coleoptera: Coccinellidae) to B. bassiana has been demonstrated: Hippodamia convergens Guérin-Méneville (James et al. 1995), A. bipunctata (Roy et al. 2007), C. septempunctata (Roy et al. 2007), Coleomegilla maculata lengi Timberlake (Todorova et al. 1996, 2000), Serangium parcesetosum Sicard (Poprawski et al. 1998), Olla v-nigrum (Mulsant) (Cottrell and Shapiro-Ilan 2003) and Cryptolaemus montrouzieri Mulsant (Smith and Krischik 2000). In contrast, a number of studies have demonstrated the resilience of H. axyridis to B. bassiana (Cottrell and Shapiro-Ilan 2003; Roy et al. 2007). In North America one of the overwintering habitats of $H$. axyridis is under bark in pecan orchards (Cottrell and Shapiro-Ilan 2003). Adults of the native ladybird O. v-nigrum are also found in this overwintering location and are commonly recorded infected with B. bassiana (Cottrell and Shapiro-Ilan 2003); whereas H. axyridis are not. Cottrell and Shapiro-Ilan (2003) demonstrated in laboratory studies that $H$. axyridis is extremely resistant to $B$. bassiana infection. Further studies using various isolates of B. bassiana support this notion. Roy et al. (2007) showed that A. bipunctata and C. septempunctata are highly susceptible to doses of $10^{7}$ spores $\mathrm{ml}^{-1}$ but even doses of $B$. bassiana exceeding $10^{9}$ spores $\mathrm{ml}^{-1}$ have limited impact on $H$. axyridis. However, $B$. bassiana appears to have a sublethal effect on $H$. axyridis and even low doses $\left(10^{5}\right.$ spores $\left.\mathrm{ml}^{-1}\right)$ reduce egg production significantly (Roy et al. 2007). 
There is one further fungal entomopathogen of coccinellids worthy of note: Hesperomyces virescens Thaxter (Ascomycota: Laboulbeniales). This intriguing fungus is an obligate ectoparasite that infects many coccinellids worldwide (Nalepa and Weir 2007). Hesperomyces virescens has been reported infecting Chilocorus stigma (Say) (Coleoptera: Coccinellidae) (Thaxter 1891), A. bipunctata (Welch et al. 2001), H. axyridis (Garcés and Williams 2004), Chilocorus bipustulatus (L.) (Coleoptera: Coccinellidae) (Kamburov et al. 1967; Applebaum et al. 1971), and Coccinula crotchi (Lewis) (Coleoptera: Coccinellidae) and Coccinula sinensis Weise (Coleoptera: Coccinellidae) (M. Majerus and R. Ware personal observation). This fungus is often reported on the ventroposterior of males and the dorsoposterior of females; a sexual dimorphism that reflects the major transmission mechanism which is thought to be via direct contact during mating (Weir and Beakes 1996; Welch et al. 2001; Riddick and Schaefer 2005). Nalepa and Weir (2007) have studied the interactions between $H$. virescens and $H$. axyridis in detail. In a field survey in North Carolina they demonstrated infection levels of $22-38 \%$ at the beginning of winter increasing to $62 \%$ by the end of winter. These overwintering ladybirds did not exhibit the characteristic elytral distribution of $H$. virescens as hypothesised by the sexual transmission theory. In contrast, fungal thalli were distributed in accordance with direct contact through aggregation and orientation behaviour, notably on the anterior part of the body. A similar pattern was reported for A. bipunctata which, when collected from overwintering aggregations, had fungal thalli distributed at the margins and front angles of the elytra (Weir and Beakes 1996). Nalepa and Weir (2007) conclude that direct transmission through contact with conspecifics is the most important mechanism for transmission of $H$. virescens and sexual contact is of primary importance in the mating season but aggregation in winter also plays a significant role.

Laboulbeniales characteristically do not penetrate the insect cuticle, however, $H$. virescens is one of the few species, in this family, to exhibit rhizoidal penetration into the host body by production of a circular appressorium, which attaches and penetrates the host cuticle (Weir and Beakes 1996). Even though this fungus invades the host there are no known deleterious impacts on the beetle (Nalepa and Weir 2007). However, H. virescens is suspected to have a negative effect on C. bipustulatus, through increased mortality (Applebaum et al. 1971; Kamburov et al. 1967). Heavy infections could also impede flight, foraging and mating but this requires further investigation.

It is also of note that some Asian populations of $H$. axyridis are strongly female biased, due to the presence of a male-killing bacterium of the genus Spiroplasma (Majerus et al. 1998). The bacterium is maternally inherited in the cytoplasm of eggs, but not sperm. As a consequence, it kills male hosts early in embryogenesis. In doing so, the male-killer makes the soma of these dead male eggs available as a food source to infected female sibling neonate larvae, providing them with a significant fitness advantage (Majerus and Hurst 1997; Majerus 2006). Prevalence of this Spiroplasma in populations of H. axyridis in its native range is variable, but can reach $80 \%$. The male-killer has not been reported from $H$. axyridis in its introduced range. Intuitively, it seems likely that introduction of malekiller infected females into populations of $H$. axyridis in Europe and North America would depress $H$. axyridis, because half the offspring (the males) of infected females would die in the eggs. The male-killer would spread naturally through the population to an equilibrium prevalence dictated by the vertical transmission efficiency of the male-killer $(>0.99$ for this Spiroplasma), any direct fitness effects that the male-killer has on females and the level of benefit gained by infected females as a result of the death and consumption of their male siblings (Hurst et al. 1997). The death of half the infected female's offspring would seem to be beneficial in reducing host population size, and consequently both intraguild 
competition and predation imposed by $H$. axyridis. However, this may not be the case in practice. As male $H$. axyridis can mate with many females, a bias in the sex ratio towards females is unlikely to lead to reduced fertility in females. Moreover, as $H$. axyridis larvae are highly cannibalistic, loss of a significant proportion of male progeny during embryogenesis may simply lead to a reduction in cannibalism of immatures, and not to a reduction in the adult population. Finally, as female ladybirds eat considerably more than males (Hodek 1996), the level of intraguild competition may actually be increased as a result of biasing the population sex ratio in favour of females. Due to these uncertainties, use of a male-killer in an attempt to reduce $H$. axyridis populations should not be undertaken until a full analysis of the consequences of such an action has been conducted.

Current research indicates that, under current knowledge, pathogens are unlikely to be suitable biological control agents for $H$. axyridis. The fungi examined so far (mainly $B$. bassiana) lack efficacy and specificity towards $H$. axyridis and could impact on nontarget coccinellids and other insects. Nevertheless, the development of a novel strategy utilising pathogens as a component of a complex control strategy should not be ruled out. The sublethal effects of disease require further research and could provide a solution to controlling $H$. axyridis. Furthermore, $H$. axyridis should be screened throughout its native and non-native distribution to thoroughly assess the diversity of pathogens (fungi, protists, bacteria and viruses) and other "hitchhikers" (nematodes and other parasites) associated with it. One of these could be the key to control.

\section{Predators}

As other ladybirds, $H$. axyridis is considered to be largely protected from generalist predators thanks to its alkaloid-rich defence secretions and its aposematic colouration. Nevertheless, Nechayev and Kuznedsov (1973) mention eight species of birds feeding on H. axyridis in Russia. Although Kuznetsov (1997) reports that the two bird species Picus canus Gmelin (Piciformes: Picidae) and Sitta europaea L. (Passeriformes: Sittidae) will feed on $H$. axyridis in mass overwintering aggregations, he concludes that predation of coccinellids, including $H$. axyridis, by birds is generally rare. Eggs and larvae may also be preyed upon by other coccinellids (Pell et al. 2007; Ware and Majerus 2007) and by predatory bugs (De Clercq et al. 2003), although, in general, H. axyridis has better physical and chemical defences against predation than most ladybirds (see Pell et al. 2007, for review). It is also less attacked by ants and spiders than other ladydirds (Dutcher et al. 1999; Yasuda and Kimura 2001). It is very unlikely that any invertebrate or vertebrate predator will ever play a significant role in the natural control of $H$. axyridis in Europe or the Americas.

\section{Parasitoids}

Only two parasitoid species were found on $H$. axyridis in its introduction range and these have never been reported as being a significant source of mortality. The tachinid fly Strongygaster triangulifera (Loew) (Diptera: Tachinidae) was found in adult beetles in North Carolina (Nalepa et al. 1996; Nalepa and Kidd 2002) and Oregon (Katsoyannos and Aliniazee 1998). All were reared from overwintering beetles. Parasitism was very variable between sites and from year to year but, on average, only $2-4 \%$ of the beetles were parasitized. In Oregon, Katsoyannos and Aliniazee (1998) observed parasitism rates of 
$6.7-15.4 \%$ by dissection and $4.8 \%$ by rearing. Strongygaster triangulifera is a small parasitic fly that is widely distributed in North America and very polyphagous. It is most frequently reported as a parasitoid of adult Coleoptera and there are scattered reports of parasitism within the Dermaptera, Hemiptera, Orthoptera and Lepidoptera (Reeves and O'Hara 2004).

The braconid wasp Dinocampus coccinellae (Schrank) (Hymenoptera: Braconidae) is a common endoparasitoid of ladybirds in Europe, Asia and the Americas. Females usually parasitise adults, although larvae and pupae can also be attacked, in which case the development continues in the adult beetle (Obrycki et al. 1985). Dinocampus coccinellae is recorded from many ladybirds of the subfamily Coccinellinae but shows strong preferences for some large species. For example, in the UK it mainly attacks C. septempunctata, Coccinella undecimpunctata L. (Coleoptera: Coccinellidae) and Harmonia quadripunctata Pontoppidan (Coleoptera: Coccinellidae) (Majerus 1997). In North and South America it is most often recorded from Coleomegilla maculata (DeGeer) (e.g. Obrycki et al. 1985; Berti Filho and Costa 1995; Hoogendoorn and Heimpel 2002). It is occasionally observed on H. axyridis in North America (Hoogendoorn and Heimpel 2002; Firlej et al. 2005), Europe (Koyama and Majerus 2007) and East Asia (Liu 1950; Maeta 1969; Park et al. 1996). In Europe and North America, H. axyridis is considered as a marginal host for D. coccinellae. Hoogendoorn and Heimpel (2002) compared parasitism in $H$. axyridis and the native ladybird $C$. maculata in the USA. They found similar parasitism rates by dissection of field-collected beetles, varying from $9 \%$ to $24 \%$. But the emergence rate was much higher in $C$. maculata than in $H$. axyridis, hardly any parasitoid larvae being able to complete their development in $H$. axyridis. In laboratory assays, female wasps attack the two hosts readily, but larvae were found in $90 \%$ of the attacked C. maculata and in only $7 \%$ of the $H$. axyridis. Similar observations were made in Canada (Firlej et al. 2005) and, in the UK (Koyama and Majerus 2007). Koyama and Majerus (2007) have shown that while the attack rates of D. coccinellae on $H$. axyridis and C. septempunctata are similar, successful development in $H$. axyridis is much lower than in C. septempunctata. Firlej (2006) observed that, in H. axyridis, parasitism by D. coccinellae was successful only when the ladybird larvae were parasitised, whereas adults were attacked but no parasitoid developed in these adults. Firlej (2006) suggested that the poor performance of $D$. coccinellae in $H$. axyridis may be at least partly due to the lower number of teratocytes produced by the parasitoid in $H$. axyridis compared to suitable hosts. In Asia, D. coccinellae is less commonly reared from $H$. axyridis than from, e.g. Coccinella septempunctata brucki Mulsant (Coleoptera: Coccinellidae) (Maeta 1969). However, successful parasitism is higher in Asia compared to Europe (Liu 1950; Maeta 1969; Park et al. 1996), suggesting either that Asian populations of D. coccinellae are better adapted to $H$. axyridis than European populations, or that invasive populations of $H$. axyridis are more resistant to D. coccinellae.

Other parasitoids of $H$. axyridis are known only from their area of origin, but details on their impact, biology and ecology are scarce. The tachinid fly Medina (=Degeeria) luctuosa (Meigen) (Diptera: Tachinidae) was found in adult beetles collected in OctoberNovember in Korea (Park et al. 1996). Parasitism rates fluctuated between $0.7 \%$ and $21.1 \%$. In laboratory rearing, parasitism by M. luctuosa shortened the life span and prevented egg development and oviposition. The true identity of this parasitoid is questionable because, in Europe, M. luctuosa is specific to adult chrysomelids of the genus Haltica, whereas many Coccinellidae, but not yet $H$. axyridis, are parasitized by a closely-related species, Medina separata (Meigen) (Diptera: Tachinidae), which was sometimes wrongly identified as M. luctuosa (Tschorsnig and Herting 1994). A gregarious pupal parasitoid, the 
phorid fly Phalacrotophora philaxyridis Disney (Diptera: Phoridae) was described from Japan (Disney 1997). A congeneric species, Phalacrotophora fasciata (Fallén) (Diptera: Phoridae) is reported from H. axyridis pupae in the Russian Far East by Kuznetsov (1997) and Park et al. (1996) cite a Phalacrotophora sp. parasitizing $0.4-6.7 \%$ of the pupae in Korea, 1-8 adults emerging from a single host pupa. The host range of $P$. philaxyridis is unknown but, in Europe, P. fasciata and another species, Phalacrotophora berolinensis Schmitz (Diptera: Phoridae), parasitize several coccinellid species (Hodek 1973; Majerus and Kearns 1989).

From this survey, it appears that the potential of using parasitoids for the biological control of $H$. axyridis in its area of introduction is limited. The parasitoids found on H. axyridis in Europe and North America are of marginal importance and, in the case of $D$. coccinellae, not well adapted to $H$. axyridis. Thus, there is little prospect for their use in conservation or augmentative biological control programmes. The specificity of the parasitoids found only in Asia remains to be investigated but they belong to genera that are known to comprise rather polyphagous species, at least within the family Coccinellidae. It must be noted, however, that our knowledge on the parasitoid complex of $H$. axyridis in its native range is based on a couple of studies in Japan and Korea, whereas the largest part of the native range has never been investigated for parasitism. The parasitoid complex of indigenous ladybirds often comprises more than three species. For example, at least seven parasitoids are known from C. septempunctata in Europe (Klausnitzer and Klausnitzer 1997). Larval parasitism has never been recorded on $H$. axyridis, although several parasitoids of the genera Aprostocetus, Oomyzus and Tetrastichus (Hymenoptera: Eulophidae), Homalotylus (Hymenoptera: Encyrtidae) and Pachyneuron (Hymenoptera: Pteromalidae) are common larval parasitoids of Coccinellidae (Klausnitzer and Klausnitzer 1997; Noyes 2007). Larval parasitism by Encyrtidae or Eulophidae may kill up to 90-95\% of ladybird populations and severely affect their impact as aphid or coccid predators (Iperti 1964; Hodek 1973). Thus, it would be worthwhile investigating parasitism in H. axyridis in regions which have never or rarely been surveyed, such as China and Siberia. It remains to be seen whether a parasitoid may be found that is totally specific to $H$. axyridis, as this would be a pre-requirement for introduction into Europe or America. Most ladybird parasitoids are specific to Coccinellidae or to coccinellid sub-families, but often rather polyphagous at family or sub-family level (Klausnitzer and Klausnitzer 1997). An exception may be Homalotylus platynaspidis Hofer (Hymenoptera: Encyrtidae), which, in Europe, may be specific to Platynaspis luteorubra (Goeze) (Coleoptera: Coccinellidae) (Hodek 1973), although it has been recently reported from Scymnus subvillosus (Goeze) (Coleoptera: Coccinellidae) in Russia (Noyes 2007).

\section{Nematodes}

To our knowledge, nematodes have never been recorded from wild populations of H. axyridis. Parasitic nematodes of the families Allantonematidae and Mermitidae are able to infest ladybird populations (Iperti 1964). For example, Iperti (1964) found a parasitic nematode (later described as Parasitylenchus coccinellinae Iperti \& Van Waerebeke (Tylenchida: Allantonematidae) in Iperti and van Waerebeke (1968)) parasitizing the intestine of adults of several ladybirds, particularly Propylea quatuordecimpunctata (L.) (Coleoptera: Coccinellidae) and Oenopia conglobata (L.) (Coleoptera: Coccinellidae). Parasitism rates in P. quatuordecimpunctata reached up to $46 \%$ in early autumn. The infection was not lethal, but strongly reduced egg maturation (Iperti 1964). Commercially 
available entomopathogenic nematodes (Heterorhabditis bacteriophora Poinar (Nematoda: Heterorhabditidae) and Steinernema carpocapsae (Weiser) (Nematoda: Steinernematidae)) were tested on $H$. axyridis and other ladybirds by Shapiro-Ilan and Cottrell (2005) in the USA. They demonstrated that while $H$. axyridis and $C$. septempunctata (invasive alien species in USA) are susceptible to nematodes they were both more resistant than two native species (C. maculata and $O$. v-nigrum).

\section{Parasitic mite}

The mite Coccipolipus hippodamiae (McDaniel \& Moril) (Acari: Podapolipidae) is a sexually transmitted ectoparasite of adult coccinellids in Europe (McDaniel and Morrill 1969; Webberley et al. 2004). It lives on the ventral surface of the elytra. Larval C. hippodamiae pass between male and female hosts during copulation, in either direction (Hurst et al. 1995). Once on a new host, larval mites embed their mouthparts into the ventral surface of the host elytra and feed on haemolymph, metamorphosing into adults. Within a few weeks, much of the ventral surface of the elytra is covered with mite adults, eggs and larvae (Webberley et al. 2002). In A. bipunctata, the mite has strong negative effects on male and female hosts, increasing overwintering mortality, particularly in males (Webberley et al. 2002) and reducing both fecundity and egg viability in females, the latter eventually to zero (Hurst et al. 1995). Similar, but marginally less extreme, negative effects of the mite have been found on female Adalia decempunctata (L.) (Coleoptera: Coccinellidae) and $O$. conglobata (Webberley et al. 2004). Coccipolipus hippodamiae is found on a variety of coccinellids, but shows highest prevalence on A. bipunctata, where over $90 \%$ of some populations are infected by late summer (Webberley et al. 2004). Comparative analysis of prevalence levels of the mite, on four European coccinellids, has indicated that prevalence is positively correlated to promiscuity and voltinism (Webberley et al. 2006).

Due to the high negative effects that $C$. hippodamiae imposes on its hosts, coupled to the behaviour and ecology of $H$. axyridis in Europe, this mite is a possible candidate for use as a biological control agent of $H$. axyridis. Importantly, $H$. axyridis has behavioural characteristics (high promiscuity, no requirement for dormancy before reproducing, multivoltinism, over-lapping generations) to facilitate both horizontal transmission and transmission down the generations of the mite, leading to high prevalence once the mite has established. What is currently not known is whether $C$. hippodamiae can use $H$. axyridis as a host, and, if it can, whether the strong negative effects that the mite imposes on A. bipunctata will also be imposed on $H$. axyridis. Encouragingly, preliminary tests in which $C$. hippodamiae have been artificially transferred from wild French Harmonia quadripunctata to $H$. axyridis have shown that the mite can feed and survive on $H$. axyridis (M. Majerus unpublished data). Moreover, transfer to $H$. axyridis might come about naturally, for inter-specific hybrid matings between $H$. axyridis and A. bipunctata has been recorded in the field in Europe (Pascoe et al. 2007), and Webberley et al. (2004) report that mites can successfully transfer between species during interspecific hybrid matings. If it is proven that $C$. hippodamiae is detrimental to $H$. axyridis and if the transfer from European ladybirds does not occur naturally, artificially infested $H$. axyridis adults could be inoculated to field populations for further propagation. Coccipolipus hippodamiae also occurs in North America (McDaniel and Morrill 1969), and may thus have a role to play there. However, given the wide host range of the mite, an appropriate risk assessment would be required before integrating this biological control agent into management 
programmes. An introduction to continents from which $C$. hippodamiae has not been reported (South America, Africa) should not be considered, although other congeneric mites with similar ecologies that occur on these continents may be considered as alternatives.

The efficacy of sexually transmitted diseases (STD) such as $C$. hippodamiae and $H$. virescens as controlling agents for $H$. axyridis might be improved in an IPM strategy that also involves the male-killer of $H$. axyridis. In species in which both sexes are highly promiscuous, such as $H$. axyridis, the rate of spread of an STD will be greater in populations in which sex ratios are female biased because males, due to their scarcity, will have more mating partners and so more opportunity to both contract and to pass on the disease (Majerus 2003). Thus, in a population of $H$. axyridis that is female biased due to the presence of a male-killer, an STD, such as $C$. hippodamiae, would reach higher prevalence than in a population with a $1: 1$ sex ratio.

\section{Conclusions}

Developing control methods against the harlequin ladybird remains a challenge, for several reasons. It is the first time a predatory ladybird, or any other predatory beetle, requires control. Thus, there is no previous experience on which to base new management strategies, and research to date has been very limited. Furthermore, as most other ladybirds are considered beneficial insects, control methods against $H$. axyridis will have to be highly specific to avoid non-target effects. Suitable control methods will continue to be developed to prevent or control aggregations in houses and fruit damage. Besides the use of chemical insecticides, which are efficient but should preferably be avoided to prevent their negative impact on human health and the environment, the most promising new strategies are the development of new cultural practices in vineyards and, especially of new trapping methods based on semiochemicals. Our current understanding of pheromonal and kairomonal communication by coccinellids, and specifically $H$. axyridis, is still limited. However, there are many effective model systems using semiochemical methods for controlling pest insects, which could prove to be informative in developing strategies for controlling $H$. axyridis.

While control methods presently used or under development may eventually solve the problems in buildings, orchards or vineyards, it is very unlikely that any of these methods will ever limit the impact of outbreak $H$. axyridis populations on native biodiversity. Unless a native European or American natural enemy (e.g. C. hippodamiae) adapts itself to the new invader and provides control, the only method that may eventually lower invasive population densities in a sustainable way is the importation of natural enemies from the region of origin. However, $H$. axyridis is a difficult target for classical biological control, partly because the invasion of $H$. axyridis is, in itself, most probably the result of bad biological control practices. Thus convincing the public, authorities and a part of the scientific community that a biological control agent needs to be introduced to control another biological control agent that turned bad may be challenging. In addition, a candidate biological control agent should be specific to $H$. axyridis. The chance of finding a specific pathogen or parasitoid in Asia is low but not negligible. As in all classical biological control programmes, the risk of introducing an exotic agent has to be weighted against the risk of doing nothing or the risk related to traditional control measures. In the case of $H$. axyridis, the introduction of a biological control agent should be considered only if there are clear signs that native ladybirds, or other aphidophagous insects, are 
seriously threatened over a significant part of their distribution range. At present, the priority for research is to gather more reliable and quantitative data on the exact impact of $H$. axyiridis on the native fauna in the invaded regions. In the meantime, comparative assessments of mortality factors affecting populations of $H$. axyridis in the native range and the areas of introduction should be carried out, e.g. through life table analysis, to understand which factors limit population densities in the native range and which do not occur in the regions of introduction. These studies would also allow the identification of potential classical biological control agents that could be considered for introduction, should the situation in the invaded regions become dramatic for native biodiversity.

Finally, it must be noted that, in North America, there are various agricultural contexts where $H$. axyridis is highly valued as a biological control agent, particularly in corn, soybeans, citrus and apples (Koch 2003; Pervez and Omkar 2006). A control method that would provide area wide reductions in $H$. axyridis populations might also result in reduced levels of aphid biocontrol and, thus, create a conflict of interest between the agricultural sector and conservationists.

Acknowledgements Marc Kenis and Renate Zindel are supported by a grant from the Swiss Federal Office for the Environment (F232-0377) and the EU FP6 project ALARM (GOCE-CT-2003-506675).

\section{References}

Adriaens T, Branquart E, Maes D (2003) The multicoloured Asian ladybird Harmonia axyridis Pallas (Coleoptera : Coccinellidae), a threat for native aphid predators in Belgium? Belg J Zool 133:201-287

Adriaens T, San Martin y Gomez G, Maes D (2007) Invasion history, habitat preferences and phenology of the invasive ladybird Harmonia axyridis in Belgium. BioControl (this issue). doi:10.1007/ s10526-007-9137-6

Agarwala BK, Yasuda H, Kajita Y (2003) Effect of conspecific and heterospecific feces on foraging and oviposition of two predatory ladybirds: role of fecal cues in predation avoidance. J Chem Ecol 29: $357-376$

Anonymous (2005) Viticulture pest alert. Multicolored Asian ladybeetle (Harmonia axyridis) on grapes. Missoury State University. http://www.mtngrv.missouristate.edu/Publications/PestAlert1.htm. Cited 20 Aug 2007

Applebaum S, Kfir R, Gerson U, Tadmor U (1971) Studies on the summer decline of Chilocorus bipustulatus in citrus groves in Israel. Entomophaga 16:433-444

Baniecki J, Dabaan ME, Freeborn J, Cheves B, Richmond D (2004) Multicolored Asian ladybird (Harmonia axyridis). West Virginia University extension Service. http://www.wvu.edu/ agexten/ipm/insects/ ladybeetle.htm. Cited 20 Aug 2007

Berti Filho E, Costa VA (1995) Perilitus coccinellae (Schrank, 1802) (Hymenoptera, Braconidae, Euphorinae), a parasitoid of Coleomegilla maculata (DeGeer) (Coleoptera, Coccinellidae). Rev Agric (Piracicaba) 70:80

Brown PMJ, Adriaens T, Bathon H, Cuppen J, Goldarazena A, Hägg T, Kenis M, Klausnitzer BEM, Kováŕ I, Loomans AJM, Majerus MEN, Nedved O, Pedersen J, Rabitsch W, Roy HE, Ternois V, Zakharov IA, Roy DB (2007) Harmonia axyridis in Europe: spread and distribution of a non-native coccinellid. BioControl (this issue). doi:10.1007/s10526-007-9132-y

Burns DA, McDonnell JJ, Hemptinne J-L, Lognay G, Dixon AFG (1998) Mate recognition in the two-spot ladybird beetle, Adalia bipunctata: role of chemical and behavioural cues. J Insect Physiol 44:1163-1171

Byers JA (2004) Chemical ecology of bark beetles in a complex olfactory landscape. In: Lieutier F, Day KR, Battisti A, Grégoire J-C, Evans HF (eds) Bark and wood boring insects in living trees in Europe, a synthesis. Kluwer Academic Publishers, Dordrecht

Cook SM, Khan ZR, Pickett JA (2007) The use of push-pull strategies in integrated pest management. Annu Rev Entomol 52:375-400

Cottrell TE, Shapiro-Ilan DI (2003) Susceptibility of a native and an exotic lady beetle (Coleoptera: Coccinellidae) to Beauveria bassiana. J Invertebr Pathol 84:137-144 
De Clercq P, Peeters I, Vergauwe G, Thas O (2003) Interactions between Podisus maculiventris and Harmonia axyridis, two predators used in augmentative biological control in greenhouse crops. BioControl 48:39-55

Disney RHL (1997) A new species of Phoridae (Diptera) that parasitises a wide-spread Asian ladybird beetle (Coleoptera: Coccinellidae). Entomologist 116:163-168

Dowd PF, Vega FE (2003) Autodissemination of Beauveria bassiana by sap beetles (Coleoptera: Nitidulidae) to overwintering sites. Biocontrol Sci Technol 13:65-76

Dutcher JD, Estes PM, Dutcher MJ (1999) Interactions in entomology: aphids, aphidophaga and ants in pecan orchards. J Entomol Sci 34:40-56

Firlej A (2006) Interaction du parasitö̈de Dinocampus coccinellae avec la coccinelle exotique Harmonia axyridis Pallas et la coccinelle indigène Coleomegilla maculata lengi Timberlake. PhD Thesis, Université du Québec à Montréal, Canada

Firlej A, Boivin G, Lucas E, Coderre D (2005) First report of parasitism of Harmonia axyridis parasitism by Dinocampus coccinellae schrank in Canada. Biol Invasions 7:553-556

Galvan TL, Koch RL, Hutchison WD (2005a) Effects of spinosad and indoxacarb on survival, development and reproduction of the multicolored Asian lady beetle (Coleoptera: Coccinellidae). Biol Control 34:108-114

Galvan TL, Koch RL, Hutchison WD (2005b) Toxicity of commonly used insecticides in sweet corn and soybean to the multicolored Asian lady beetle (Coleoptera: Coccinellidae). J Econ Entomol 98:780-789

Galvan TL, Burkness EC, Hutchison WD (2006a) Efficacy of selected insecticides for management of the multicolored Asian lady beetle on wine grapes near harvest. Plant Health Prog. doi:10.1094/ PHP-2006-1003-01-RS

Galvan TL, Burkness EC, Hutchison WD (2006b) Influence of berry injury on infestations of the multicolored Asian lady beetle in wine grapes. Plant Health Prog. doi:10.1094/PHP-2006-0607-01-BR

Galvan TL, Burkness EC, Hutchison WD (2006c) Wine grapes in the Midwest: reducing the risk of the multicolored Asian lady beetle. Public. 08232. University of Minnesota Extension Service, St. Paul

Galvan TL, Koch RL, Hutchison WD (2006d) Toxicity of indoxocarb and spinosad to the multicolored Asian lady beetle (Coleoptera: Coccinellidae) via three routes of exposure. Pest Manag Sci 62:797-804

Galvan TL, Burkness EC, Hutchison WD (2007) Enumerative and binomial sequential sampling plans for the multicolored Asian lady beetle (Coleoptera: Coccinellidae) in wine grapes. J Econ Entomol 100:1000-1010

Garcés S, Williams R (2004) First record of Hesperomyces virescens Thaxter (Laboulbeniales: Ascomycetes) on Harmonia axyridis (Pallas) (Coleoptera: Coccinellidae). J Kansas Entomol Soc 77:156-158

Ginsberg HS, Lebrun RA, Heyer K, Zhioua E (2002) Potential nontarget effects of Metarhizium anisopliae (Deuteromycetes) used for biological control of ticks (Acari: Ixodidae). Environ Entomol 31:1191-1196

Hassanali A, Njagi PGN, Bashir MO (2005) Chemical ecology of locusts and related acridids. Annu Rev Entomol 50:223-245

Hemptinne J-L, Lognay G, Doumbia M, Dixon AFG (2004) Chemical nature and persistence of the oviposition deterring pheromone in the tracks of the larvae of the two spot ladybird, Adalia bipunctata (Coleoptera: Coccinellidae). Chemoecology 11:43-47

Hills LD (1969) Biological pest control: report 3. Henry Doubleday Research Association, Essex

Hodek I (1973) Biology of coccinellidae. Dr. W. Junk N. V., Publishers, The Hage

Hodek I (1996) Food relationships. In: Hodek I, Honek A (eds) Ecology of coccinellidae. Kluwer Academic Publishers, Dordrecht

Hoogendoorn M, Heimpel GE (2002) Indirect interactions between an introduced and a native ladybird beetle species mediated by a shared parasitoid. Biol Control 25:224-230

Huelsman MF, Kovach J (2004) Behavior and treatment of the multicolored Asian lady beetle (Harmonia axyridis) in urban environments. Am Entomol 50:163-164

Hurst GDD, Sharpe RG, Broomfield AH, Walker LE, Majerus TMO, Zakharov IA, Majerus MEN (1995) Sexually transmitted disease in a promiscuous insect, Adalia bipunctata. Ecol Entomol 20:230-236

Hurst GDD, Hurst LD, Majerus MEN (1997) Cytoplasmic sex-ratio distorters. In: O'Neill SL, Hoffmann AA, Werren JH (eds) Influential passengers. Oxford University Press, UK, pp 125-154

Inclan DJ, Williams RN, Ellis MA, Fickle DS, McClure KB (2006) Managing the multicoloured Asian lady beetle in grapes, 2005. Arthrop Manag Tests 31:L7

Iperti G (1964) Les parasites des coccinelles aphidiphages dans les Alpes-Maritimes et les Basses-Alpes. Entomophaga 9:153-180

Iperti G, van Waerebeke D (1968) Description, biologie et importance d'une nouvelle espèce d'Allantonematidae (Nématoda), parasite des Coccinelles aphidiphages: Parasitylenchus coccinellinae, n. sp. Entomophaga 13:107-119 
James RR, Shaffer BT, Croft B, Lighthart B (1995) Field evaluation of Beauveria bassiana: its persistence and effects on the pea aphid and a non-target coccinellid in alfalfa. Biocontrol Sci Technol 5:425-438

Jones CS, Boggs J (2002) Multicolored Asian lady beetle. Ohio State University Extension Fact Sheet: Entomology HSE-1030-01. http://www.ohioline.osu.edu/hse-fact/1030.html. Cited 20 August 2007

Kamburov SS., Nadel DJ, Kenneth R (1967) Observations on Hesperomyces virescens Thaxter (Laboulbeniales), a fungus associated with premature mortality of Chilocorus bipustulatus L. in Israel. Israel J Agric Res Rehovot 17:131-134

Katsoyannos P, Aliniazee MT (1998) First record of Strongygaster triangulifera (Loew) (Diptera: Tachinidae) as a parasitoid of Harmonia axyridis (Pallas) (Coleoptera: Coccinellidae) in western North America. Can Entomol 130:905-906

Klausnitzer B, Klausnitzer H (1997) Marienkäfer. Westarp Wissenschaften, Magdeburg

Klein MG, Lacey LA (1999) An attractant trap for autodissemination of entomopathogenic fungi into populations of the Japanese beetle Popillia japonica (Coleoptera: Scarabaeidae). Biocontrol Sci Technol 9:151-158

Koch RL (2003) The multicoloured Asian lady beetle, Harmonia axyridis: a review of its biology, uses in biological control and non target impacts. J Insect Sci 3:32

Koch RL, Galvan TL (2007) Bad side of a good beetle: the North American experience with Harmonia axyridis. BioControl (this issue). doi:10.1007/s10526-007-9121-1

Koch RL, Burkness EC, Wold Burkness SJ, Hutchison WD (2004) Phytophagous preferences of the multicolored Asian lady beetle (Coleoptera: Coccinellidae) to autumn ripening fruit. J Econ Entomol 97:539-544

Koch RL, Venette RC, Hutchison WD (2006) Invasions by Harmonia axyridis (Pallas) (Coleoptera: Coccinellidae) in the Western Hemisphere: implications for South America. Neotrop Entomol 35:421-434

Kovach J (2004) Impact of the multicolored Asian lady beetle as a pest of fruit and people. Am Entomol 50:165-167

Koyama S, Majerus MEN (2007) Interactions between the parasitoid wasp Dinocampus coccinellae and two species of coccinellid from Japan and Britain. BioControl (this issue). doi:10.1007/s10526-007-9138-5

Kuznetsov VN (1997) Lady beetles of the Russian far east, (Memoir series no. 1). Center for Systematic Entomology, Gainesville

Liu CL (1950) Contribution to the knowledge of Chinese Coccinellidae. X. Occurrence of Perilitus coccinellidae (Schrank), a parasite of adult Coccinelidae in North China (Hymenoptera, Braconidae). Entomol News 61:207-208

Maeta Y (1969) Biological studies on the natural enemies of some coccinellid beetles. I. On Perilitus coccinellae (Schrank). Kontyu 37:147-1166

Majerus MEN (1994) Ladybirds new naturalist series. Harper Collins, UK

Majerus MEN (1997) Parasitization of British ladybirds by Dinocampus coccinellae (Schrank) (Hymenoptera: Braconidae). Br J Entomol Nat Hist 10:15-24

Majerus MEN (2003) A new dimension to sex wars: microbes that benefit female hosts. Microbiol Today 30:68-70

Majerus MEN (2006) The impact of male-killing bacteria on the evolution of aphidophagous coccinellids. Eur J Entomol 103:1-7

Majerus MEN, Hurst GDD (1997) Ladybirds as a model system for the study of male-killing symbionts. Entomophaga 42:13-20

Majerus MEN, Kearns P (1989) Ladybirds. Naturalists' handbooks n 10. Richemond publ., Slough

Majerus TMO, Majerus MEN, Knowles B, Wheeler J, Bertrand D, Kuznetzov VN, Ueno H, Hurst GDD (1998) Extreme variation in the prevalence of inherited male-killing microorganisms between three populations of the ladybird Harmonia axyridis (Coleoptera: Coccinellidae). Heredity 81:683-669

Majerus MEN, Roy HE (2005) Scientific opportunities presented by the arrival of the harlequin ladybird, Harmonia axyridis, in Britain. Antenna 29:196-208

Majerus MEN, Strawson V, Roy HE (2006) The potential impacts of the arrival of the harlequin ladybird, Harmonia axyridis (Pallas) (Coleoptera: Coccinellidae), in Britain. Ecol Entomol 31:207-215

McCutcheon TW, Scott HR (2001) Observations of cosmetic damage on a house caused by the multicolored Asian lady beetle, Harmonia axyridis (Coleoptera: Coccinellidae). West Virginia University Extension Service. http://www.wvu.edu/ agexten/ipm/insects/beetle.pdf. Cited 20 August 2007

McDaniel B, Morrill W (1969) A new species of Tetrapolipus from Hippodamia convergens from South Dakota (Acarina: Podopolipidae). Ann Entomol Soc Am 62:1456-1458

Nalepa CA, Kidd KA (2002) Parasitism of the multicolored Asian lady beetle (Coleoptera: Coccinellidae) by Strongygaster triangulifera (Diptera: Tachinidae) in North Carolina. J Entomol Sci 37:124-127

Nalepa CA, Weir A (2007) Infection of Harmonia axyridis (Coleoptera: Coccinellidae) by Hesperomyces virescens (Ascomycetes: Laboulbeniales): role of mating status and aggregation behavior. J Invertebr Pathol 94:196-203 
Nalepa CA, Kidd KA, Ahlstrom KR (1996) Biology of Harmonia axyridis (Coleoptera: Coccinellidae) in winter aggregations. Ann Entomol Soc Am 89:681-685

Nalepa CA, Kidd KA, Hopkins DI (2000) The multicolored Asian lady beetle (Coleoptera: Coccinellidae): orientation to aggregation sites. J Entomol Sci 35:150-157

Nalepa CA, Kennedy GG, Brownie C (2005) Role of visual contrast in the alighting behavior of Harmonia axyridis (Coleoptera: Coccinellidae) at overwintering sites. Environ Entomol 34:425-431

Nechayev VA, Kuznetsov VN (1973) Avian predation on coccinellids in Primorie region. Entomofauna Sovetskogo Dalnego Vostoka, Vladivostok

Noyes J (2007) Universal chalcidoidea database. Natural history museum. http://www.nhm.ac.uk/researchcuration/projects/chalcidoids/. Cited 20 August 2007

Obrycki JJ, Tauber MJ, Tauber CA (1985) Perilitus coccinellae (Hymenoptera: Braconidae): parasitization and development in relation to host-stage attacked. Ann Entomol Soc Am 78:852-854

Osawa N (1992) A life table of the ladybird beetle Harmonia axyridis Pallas (Coleoptera, Coccinellidae) in relation to the aphid abundance. Jpn J Entomol 60:575-579

Osawa N (1993) Population field studies of the aphidophagous ladybird beetle Harmonia axyridis (Coleoptera: Coccinellidae): life tables and key factor analysis. Res Popul Ecol 35:335-348

Park H, Park YC, Hong OK, Cho SY (1996) Parasitoids of the aphidophagous ladybeetles, Harmonia axyridis (Pallas) (Coleoptera: Coccinellidae) in Chuncheon areas, Korea. Korean J Entomol 26:143-147

Pascoe S, Brown PM, Majerus MEN (2007) Hybrid mating between Harmonia axyridis and Adalia bipunctata. Bull Amat Entomol Soc 66:156-159

Pell JK, Baverstock J, Roy HE, Ware RL, Majerus MEN (2007) Intraguild predation involving Harmonia axyridis: a review of current knowledge and future perspectives. BioControl (this issue). doi: $10.1007 / \mathrm{s} 10526-007-9125-\mathrm{x}$

Pervez A, Omkar A (2006) Ecology and biological control application of multicoloured Asian ladybird, Harmonia axyridis: a review. Biocontrol Sci Technol 16:111-128

Pettersson J, Ninkovic V, Glinwood R, Birkett MA, Pickett JA (2005) Foraging in a complex environmentsemiochemicals support searching behaviour of the seven spot ladybird. Eur J Entomol 102:365-370

Pickering GJ, Lin JY, Reynolds A, Soleas G, Riesen R, Brindle I (2005) The influence of Harmonia axyridis on wine composition and aging. J Food Sci 70:S128-S135

Pickering GJ, Lin JY, Reynolds A, Soleas G, Riesen R (2006) The evaluation of remedial treatments for wine affected by Harmonia axyridis. Int J Food Sci Technol 41:77-86

Pickering GJ, Ker K, Soleas GJ (2007) Determination of the critical stages of processing and tolerance limits for Harmonia axyridis for 'ladybug taint' in wine. Vitis 46:85-90

Poprawski TJ, Legaspi JC, Parker PE (1998) Influence of entomopathogenic fungi on Serangium parcesetosum (Coleoptera: Coccinellidae), an important predator of whiteflies (Homoptera: Aleyrodidae). Environ Entomol 27:785-795

Potter MF, Townsend L (2005) Asian lady beetle invasion of structures. University of Kentucky, College of Agriculture, Department of Agriculture.ENTFACT-416. http://www.ca.uky.edu/entomology/entfacts/ ef416.asp. Cited 20 Aug 2007

Ray JN, Pence HL (2004) Ladybug hypersensitivity: report of a case and review of literature. Allergy Asthma Proc 25:133-136

Reeves WK, O'Hara JE (2004) First report of Strongygaster triangulifera (Diptera: Tachinidae) as a parasitoid of a cantharid beetle, Chauliognathus pennsylvanicus (Coleoptera: Cantharidae). Can Entomol 136:661-662

Riddick EW, Aldrich JR (2004) Search for repellents, attractants and pheromones of the multicolored Asian lady beetle. Instant symposium-multicolored Asian lady beetles in agriculture and urban environments. Am Entomol 50:167-168

Riddick EW, Schaefer PW (2005) Occurrence, density and distribution of parasitic fungus Hesperomyces virescens (Laboulbeniales: Laboulbeniaceae) on multicoloured Asian beetle (Coleoptera: Coccinellidae). Ann Entomol Soc Am 98:615-624

Riddick EW, Aldrich JR, De Milo A, Davis JC (2000) Potential for modifying the behavior of the multicolored Asian lady beetle (Coleoptera: Coccinellidae) with plant-derived natural products. Ann Entomol Soc Am 93:1314-1321

Riddick EW, Aldrich JR, Davis JC (2004) Deet repels Harmonia axyridis (pallas) (Coleoptera: Coccinellidae) adults in laboratory bioassays. J Entomol Sci 39:373-386

Roy HE, Steinkraus D, Eilenberg E Hajek A, Pell JK (2006) Bizarre interactions and endgames: entomopathogenic fungi and their arthropod hosts. Annu Rev Entomol 51:331-357

Roy HE, Baverstock J, Pell JK (2008) Manipulating behaviour: a strategy for pest control? In: Ekesi S, Maniania NK (eds) Use of entomopathogenic fungi in biological pest management. Research Signpost 37/661 (2), Fort P.O., Trivandrum-695 023, Kerala, India 
Roy HE, Brown PMJ, Rothery P, Ware RL, Majerus MEN (2007) Interactions between the fungal pathogen Beauveria bassiana and three species of coccinellid: Harmonia axyridis, Coccinella septempunctata and Adalia bipunctata. BioControl (this issue). doi:10.1007/s10526-007-9122-0

Shapiro-Ilan DI, Cottrell TE (2005) Susceptibility of lady beetles (Coleoptera: Coccinellidae) to entomopathogenic nematodes. J Invertebr Pathol 89:150-156

Smith SF, Krischik VA (2000) Effects of biorational pesticides on four coccinellid species (Coleoptera: Coccinellidae) having potential as biological control agents in interiorscapes. J Econ Entomol 93: $732-736$

Thaxter R (1891) Supplementary note on North American Laboulbeniaceae. Proc Am Acad Arts Sci 25:261-270

Todorova SI, Cote J-C, Coderre D (1996) Evaluation of the effects of two Beauveria bassiana (Balsamo) Vuillemin strains on the development of Coleomegilla maculate lengi Timberlake (Col, Coccinellidae). J Appl Entomol 120:159-163

Todorova SI, Coderre D, Cote J-C (2000) Pathogenicity of Beauveria bassiana isolates toward Leptinotarsa decemlineata (Coleoptera: Chrysomelidae), Myzus persicae (Homoptera: Aphididae) and their predator Coleomegilla maculate lengi (Coleoptera: Coccinellidae). Phytoprotection 81:15-22

Tschorsnig H-P, Herting B (1994) Die Raupenfliegen (Diptera: Tachinidae) Mitteleuropas: Bestimmungstabellen und Angaben zur Verbreitung und Ökologie der Einzelnen Arten. Stuttgarter Beitr Naturk Ser A (Biol) 506:1-170

Van Driesche RG, Bellows TS Jr (1996) Biological control. Chapman \& Hall, New York

Van Emden HF, Service MW (2004) Pest and vector control. Cambridge University Press, UK

Verheggen FJ, Fagel Q, Heuskin S, Lognay G, Francis F, Haubruge E (2007) Electrophysiological and behavioral responses of the multicolored Asian lady beetle, Harmonia axyridis Pallas, to sesquiterpene semiochemicals. J Chem Ecol (in press). doi:10.1007/s10886-007-9370-6

Ware RL, Majerus MEN (2007) Intraguild predation of immature stages of British and Japanese coccinellids by the invasive ladybird Harmonia axyridis. BioControl (this issue). doi:10.1007/s10526-007-9135-8

Webberley KM, Hurst GDD, Buzcko J, Majerus MEN (2002) Lack of parasite mediated sexual selection in an insect-STD system. Anim Behav 63:131-141

Webberley KM, Hurst GDD, Husband RW, Schulenburg JHGVD, Sloggett JJ, Isham V, Buzcko J, Majerus MEN (2004) Host reproduction and a sexually transmitted disease: causes and consequences of Coccipolipus hippodamiae distribution on coccinellid beetles. J Anim Ecol 73:1195-1200

Webberley KM, Tinsley M, Sloggett JJ, Majerus MEN, Hurst GDD (2006) Spatial variation in the incidence of sexually transmitted parasites of the ladybird beetle Adalia bipunctata. Eur J Entomol 103:793-797

Weir A, Beakes GW (1996) Correlative light- and scanning electron microscope studies on the developmental morphology of Hersperomyces virescens. Mycologia 88:677-693

Welch VL, Sloggett JJ, Webberley KM, Hurst GDD (2001) Short-range clinal variation in the prevalence of a sexually transmitted fungus associated with urbanisation. Ecol Entomol 26:547-550

Williams RN, Fickle DS, McClure KB, Inclan DJ (2006) Chemical evaluations for control of the multicoloured Asian lady beetle on grapes, 2005. Arthropod Manag Tests 31:C11

Yasuda H, Kimura T (2001) Interspecific interactions in a tri-trophic arthropod system: effects of a spider on the survival of larvae of three predatory ladybirds in relation to aphids. Entomol Exp Appl 98:17-25 